\title{
SAINT PATRICK'S CATHEDRAL DARI SUDUT PANDANG KONSEP PERANCANGAN
}

\author{
Albertus Prawata \\ Architecture Department, Faculty of Engineering, Binus University \\ Jl. K.H. Syahdan No. 9, Palmerah, Jakarta Barat 11480 \\ albertus_prawata@binus.ac.id
}

\begin{abstract}
The Catholic diocese of Parramatta is well-known as the first established Catholic Church in Australia. It is the most recently completed Cathedral in Australia, designed by Romaldo Giurgola. As a foreigner, he was successfully applied the historical values and symbols of Catholic tradition shown on the design's elements and forms throughout the Cathedral. This paper explores the design of the Cathedral Church of the Catholic diocese of Parramatta which is influenced by works of other architects such as Utzon and Van Eyck. The use of natural light and different materials' quality in the interior and exterior of building are few of the design's elements applied in the Saint Patrick Cathedral.
\end{abstract}

Keywords: historical values, symbols of tradition, Catholic Church design, Saint Patrick's Cathedral.

\begin{abstract}
ABSTRAK
Paroki Saint Patrick, Parramatta, dikenal sebagai pelopor pertama gereja Katolik di Australia. Gereja Katedral ini merupakan gereja terbaru yang diselesaikan pembangunannya di Australia, yang didesain oleh Romaldo Giurgola. Sebagai warga asing Australia, perwujudan karyanya tidak terlepas dari penerapan nilainilai historis dan simbol tradisi Katolik pada beberapa elemen desain dan bentuk di Gereja Katedral ini. Artikel ini membahas tentang perancangan Gereja Katedral Keuskupan Katolik Parramatta yang banyak dipengaruhi oleh pemikiran dan karya arsitek lainnya seperti Utzon dan Van Eyck. Permainan atribut cahaya, penggunaan material yang kontras antara interior dan eksterior bangunan merupakan beberapa elemen desain yang diterapkan pada bangunan Gereja Katedral Saint Patrick.
\end{abstract}

Kata kunci: nilai historis, symbol tradisi, desain gereja Katolik, Saint Patrick’s Cathedral 


\section{PENDAHULUAN}

Paroki Saint Patrick, Parramatta dikenal sebagai pelopor pertama agama Katolik di Australia. Paroki ini memiliki sekolah Katolik tertua di Australia. Kapel rumah duka dan biara pertama juga terdapat di sini. Paroki ini juga penuh dengan nama-nama pelopor agama Katolik baik dari kalangan imam maupun awam. Perletakan batu pondasi pertama Gereja Saint Patrick dilakukan pada hari Saint Patrick pada tahun 1836 dan diresmikan dengan tata cara dan formalitas Gereja Katolik Roma, pada tanggal 28 Mei 1837. Pada tahun 1854 gereja ini berada dalam kondisi yang memprihatinkan, dan Dekan Coffey OFM memperintahkan untuk membangun sebuah gereja baru, dan batu pondasi pertama diletakan pada tanggal 13 Agustus 1854. Kemudian menara dan puncaknya baru ditambahkan pada tahun 1880an.

Pada tahun 1936 sebuah gereja baru dibangun untuk memenuhi kebutuhan umat yang semakin berkembang pesat. Bagian utama gereja dihancurkan dan hanya meninggalkan menara dan puncak menara. Jendela, pilar-pilar penghias dan salib semua digunakan kembali dan Gereja Saint Patrick terlihat sangat serupa dengan gereja yang lama, tetapi lebih besar secara keseluruhan.

Pada tahun 1986, Saint Patrick menjadi Gereja Katedral di keuskupan baru Parramatta. Pada tanggal 19 Februari 1996, terjadi kebakaran dan Gereja Katedral ini terbakar habis dan hanya menyisakan dinding batunya. Mitchell, Giurgola \& Thorp, dengan Romaldo Giurgola sebagai arsitek utamanya ditunjuk untuk merenovasi dan membangun Gereja Kathedral yang baru. Karyanya ini juga diperindah oleh karya seniman dan perupa Australia, dan menjadikan Gereja Katedral Saint Patrick’s menjadi Gereja Katedral Australia pertama di milennium baru ini yang terus menyesuaikan perkembangan jamannya. Pada tanggal 29 November 2003 Gereja Katedral Saint Patrick yang baru diresmikan. Gereja Katedral Saint Patrick yang lama sekarang menjadi Kapel Sakramen Mahakudus yang bersebelahan dengan Katedral kontemporer yang lebih besar. (Saint Patrick's Cathedral Parish Parramatta, 2011).

\section{METODE}

Pembahasan desain Gereja Katedral Saint Patrick ini menggunakan metode studi pustaka yang sebagian besar diambil dari karya-karya Romaldo Giurgola. Di samping itu, dilakukan pula analisis perbandingan desain Gereja Katedral Saint Patrick dengan desain dua gereja lainnya, yaitu Gereja Bagsvaerd karya Jorn Utzon dan gereja untuk komunitas Moluccan karya Aldo Van Eyck.

\section{HASIL DAN PEMBAHASAN}

\section{Konsep Perancangan Gereja Katedral}

Romaldo Giurgola (2005) menyatakan, dengan pentingnya sejarah tempat gereja berada, menjadi jelas bagi semua orang bahwa hubungan yang erat antara gereja lama dan yang baru merupakan suatu hal yang sangat penting baik secara simbolis maupun secara adat liturgi gereja. Ia menambahkan, bangunan eksisting dan bangunan yang baru harus dapat memberikan kontribusi untuk menjadikan tapak Gereja Katedral tersebut menjadi tempat yang sacral dan dihormati. Karena itu, tapak dan lokasi Gereja Katedral merupakan suatu tapak yang terbentuk dari tradisi terdahulu dan juga untuk menampung kegiatan dan kebutuhan saat ini. 
Pemugaran Gereja Katedral yang lama dan menjadikannya sebuah Kapel pada komplek Katedral yang baru ini, menandakan pentingnya tempat Gereja Katedral ini sebagai gereja awal Katolik Roma di Australia. Hal ini dipahami oleh Romaldo Giurgola, dan menjadikan elemen tempat menjadi elemen penting dalam desain gereja ini. Satu hal yang secara jelas ia lakukan untuk memperkuat elemen tempat ini dengan meletakan pintu masuk utama pada Kapel (Gambar 1). Hal ini menjadikan simbol pentingnya keberadaan Kapel tersebut sebagai gereja awal Katolik Roma di Australia. Komposisi dasar dua bentuk persegi panjang Gereja Katedral di dalam tapak/ lokasi ini menciptakan ruang publik yang juga melayani dan menyediakan fasilitas lainnya seperti ruang bersama (hall) dan juga gedung pasturan. Bentuk dasar desain gereja ini (Gambar 2) adalah dua buah persegi panjang yang saling mengunci, menciptakan suatu simetri yang tidak seimbang (Gambar 3), yang memberikan penekankan pada koridor pintu masuk pada Kapel dan Gereja Katedral yang baru.

Desain komplek Gereja Katedral ini difokuskan pada pembuatan empat buah ruang arsitektural utama yang dapat disatukan menjadi suatu urutan ruang luar dan ruang dalam bangunan. Ruang arsitektural pertama merupakan ruang luar yang terdapat di depan pintu masuk utama Gereja Katedral (Gambar 4) yang sekarang berupa Kapel, dan berada di depan bangunan eksisting gedung pasturan.

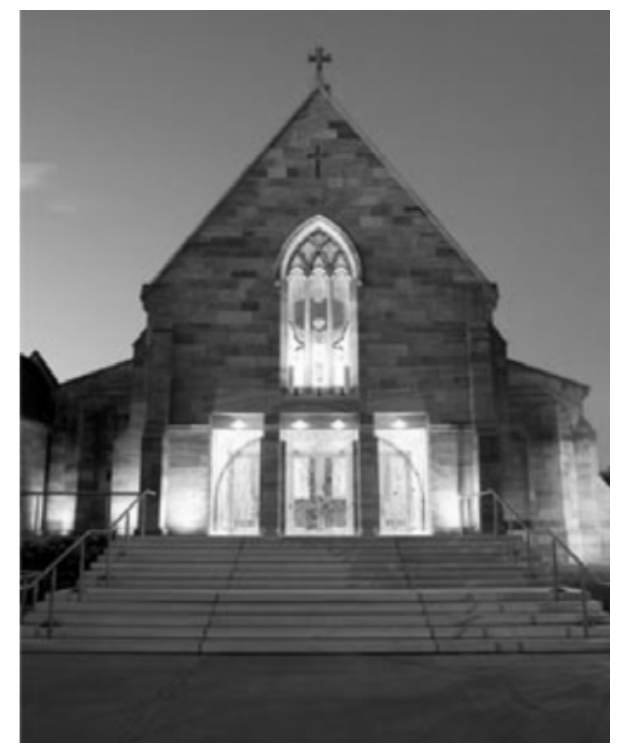

Gambar 1. Pintu masuk utama Gereja Katedral Saint Patrick (Sumber: Architecture Australia, 2006).

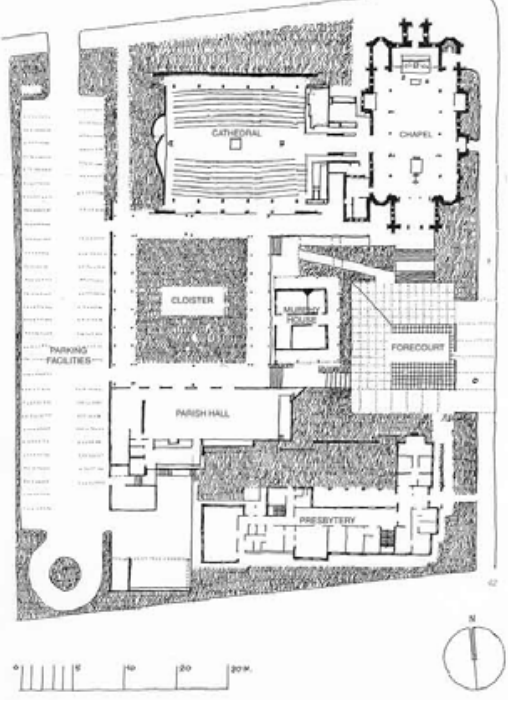

Gambar 2. Site plan Gereja Katedral Saint Patrick (Sumber: Romaldo Giurgola, 2006).

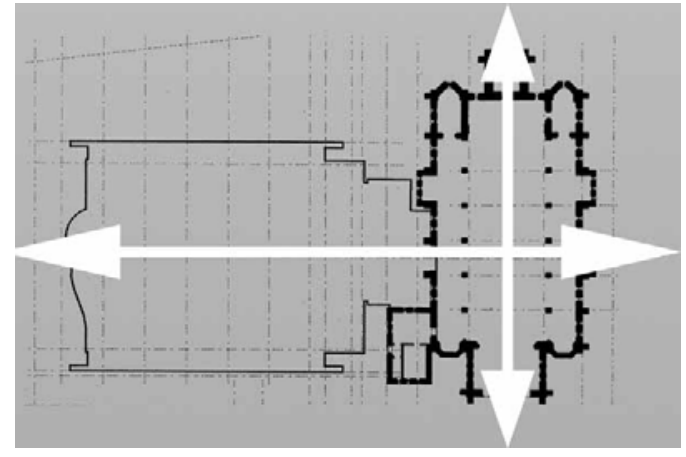

Gambar 3. Dua geometri yang terbentuk dari gereja lama dan baru yang menciptrakan simetri yang tidak sama. (Sumber: Romaldo Giurgola, 2006). 


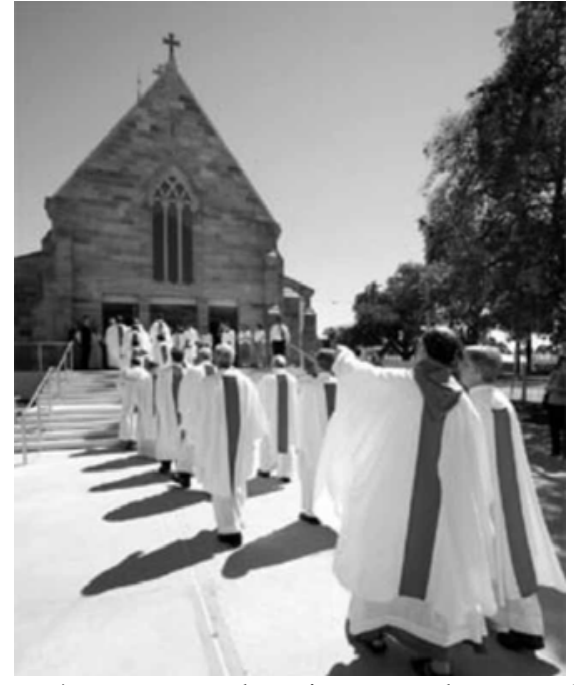

Gambar 4. Forecourt dan pintu masuk utama Gereja Katedral (Sumber: Architecture Australia, 2006).

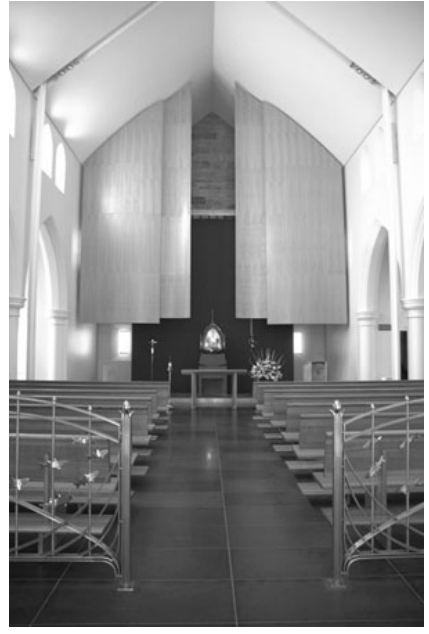

Gambar 5. Interior Kapel (Sumber: Albertus Prawata).

Ruang arsitektural yang kedua adalah interior Kapel, yang merupakan Gereja Katedral yang lama. Ruang ini memiliki kualitas vertikal, yang terbentuk oleh deretan kolom dan busur. Ruang ini adalah tempat untuk berdoa dan merefleksikan diri, dengan altar dan Tabernakel yang terletak di bagian belakang. Eksterior dan interior bangunan ini (Gambar 5) memberikan suatu suasana yang kontras. Kombinasi antara material yang lama dan yang baru menyatu secara indah pada eksterior bangunan. Hal ini menandakan pentingnya keberadaan Katedral yang lama.

Ruang berikutnya yang dapat diakses langsung melalui Kapel adalah ruang arsitektural ketiga yang merupakan ruang utama Gereja Katedral yang baru (Gambar 6). Ruang ini merupakan ruang terbesar yang memiliki kualitas horisontal yang berfungsi sebagai Gereja Katedral yang baru, dan ruang ini mampu menampung 800 orang. Pada ruangan ini Altar diletakan pada bagian tengah gereja, dengan tempat duduk umat di sisi altar. Hal ini memberikan desain kontemporer baik secara desain gereja maupun tata cara ibadatnya. Romaldo Giurgola (2005) menyatakan, perletakan altar di tengah ruang berdasarkan dari prinsip liturgi dari peraturan komisi Vatikan bertujuan untuk menciptakan partisipasi yang lebih aktif dari umat. Tempat duduk Uskup (Cathedra), terdapat pada bagian mimbar di sisi lain gereja. Hal ini memberikan momen liturgi yang berbeda-beda tetap jelas pada ekspresi dan artinya.

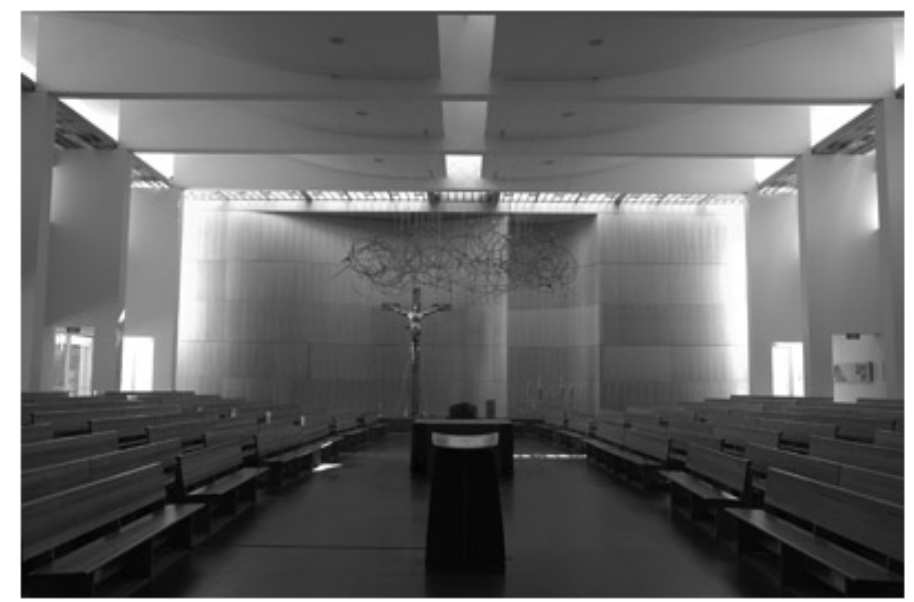

Gambar 6. Interior Gereja Katedral baru (Sumber: Albertus Prawata). 
Ruang arsitektural keempat yang dapat diakses secara dari gereja baik secara visual dan langsung adalah ruang terbuka biara (Gambar 7), yang berada diantara Gereja Katedral yang baru dan juga gedung serba guna (hall). Komplek Gereja Katedral dibentuk oleh beberapa struktur bangunan yang berbeda-beda dan juga untuk menampung berbagai aktifitas yang berbeda. Tetapi tujuan utamanya memberikan pengalaman ruang lama \& baru menjadi satu kesatuan yang baik dan tidak terpisahkan (sense of place), dan melayani untuk maksud-maksud atau nilai sejarah yang baik. Ruangruang yang tercipta pun menciptakan suatu keseimbangan dan kualitas lingkungan kota dengan memberikan keselarasan terhadap bagian-bagian yang ada di dalam komplek ini, bukan dengan menciptakan suatu elemen yang kontras dan paling menonjol. Dengan demikian, suasana yang tercipta pun dapat memberikan dan melayani pengalaman ruang yang baik terhadap tempat tersebut.

\section{Pemikiran dan karya arsitektur yang lain (Utzon \& Van Eyck)}

Pengaruh dan pemikiran arsitektur lain juga terlihat pada karya Gereja Katedral Saint Patrick ini. Karya Jorn Utzon, yaitu Gereja Bagsvaerd dan karya Aldo Van Eyck, yaitu gereja untuk komunitas Moluccan, memiliki kualitas yang bisa ditemui pada Gereja Katedral Saint Patrick karya Romaldo Giurgola.

Perbedaan eksterior (Gambar 8) dan interior (Gambar 9) pada Gereja Bagsvaerd memberikan elemen kejutan dan suasana yang sangat berbeda. Eksterior gereja tidak menunjukan bahwa bangunan tersebut adalah sebuah gereja, karena memiliki kualitas dan ekspresi bangunan pabrik atau industri. Tetapi pada saat berada di dalam interior bangunan, kesakralan dan keintiman bangunan tersebut sangat terasa dengan perbedaan material bangunan dan ditambahkan dengan atribut cahaya yang masuk ke dalam ruang gereja.

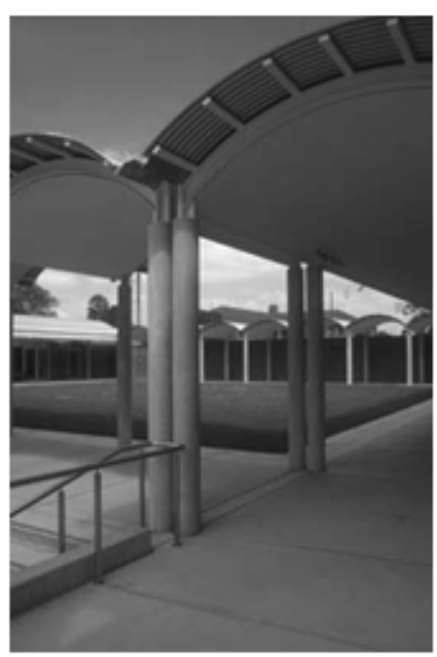

Gambar 7. Ruang terbuka biara (Sumber: Australian Institute of Architects).

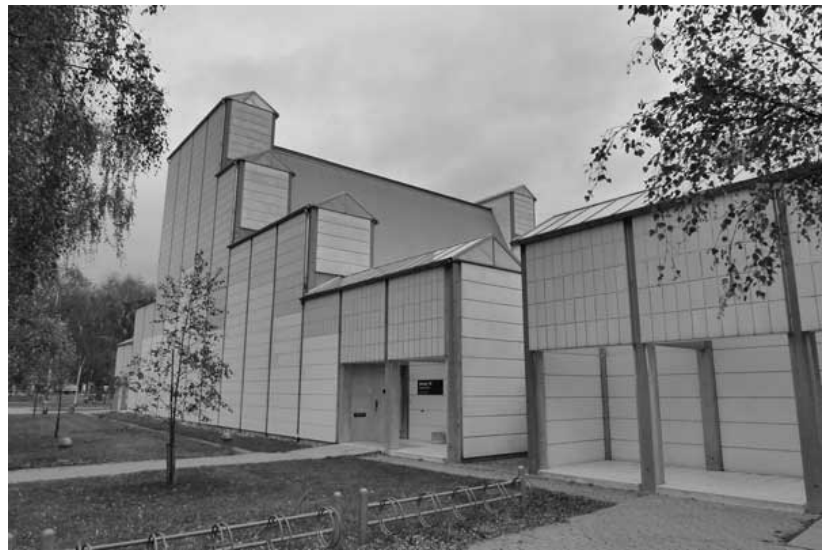

Gambar 8. Ekterior Gereja Bagsvaerd (Sumber: Toby Richardson).

Gereja untuk komunitas Moluccan di Belanda yang dirancang oleh Aldo Van Eyck juga memiliki kualitas ruang yang serupa dengan Gereja Katedral Saint Patrick. Satu hal yang mencolok adalah perletakan tata ruang liturgi yang menempatkan altar pada bagian tengah bangunan (Gambar 10). Hal ini memberikan suasana kontemporer dan pembaruan untuk meningkatkan dan menciptakan partisipasi yang aktif dalam pelaksanaan tata cara ibadat. Atribut cahaya sebagai elemen desain dalam bangunan gereja sudah banyak sekali digunakan oleh para arsitek-arsitek untuk menangkap dan menciptakan kesakralan dan kesucian tempat ibadat. 


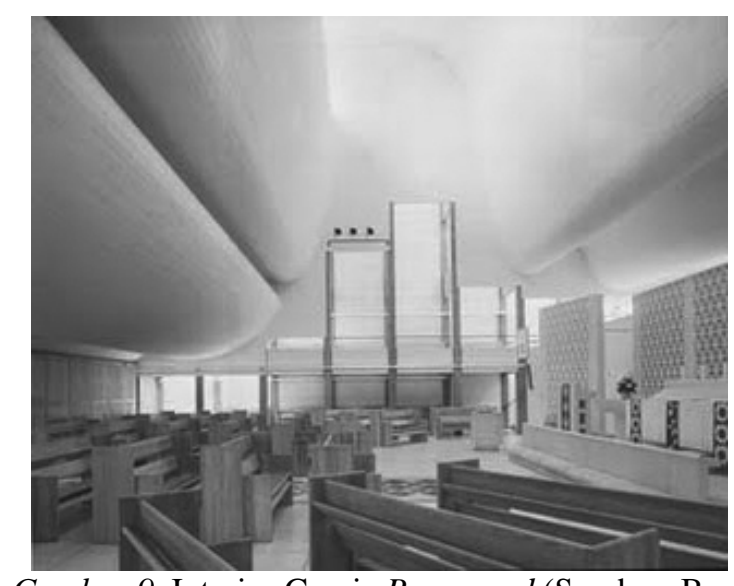

Gambar 9. Interior Gereja Bagsvaerd (Sumber: Bent Ryberg/Planet Foto).

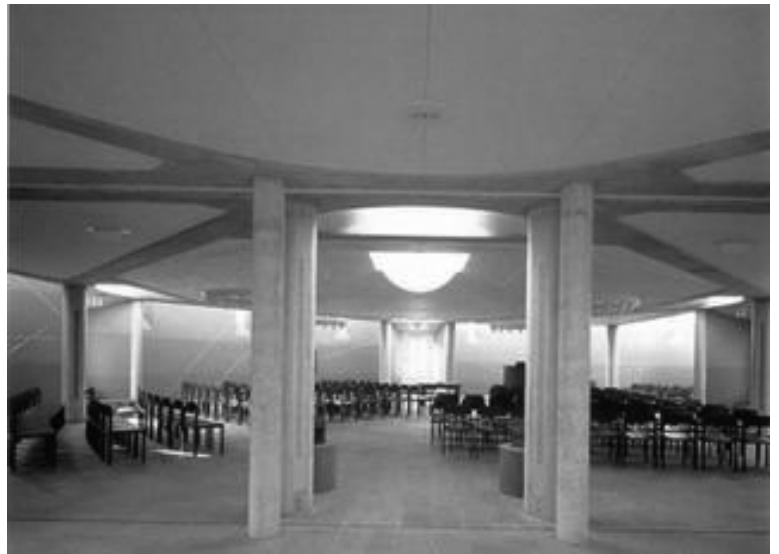

Gambar 9. Interior gereja untuk komunitas Moluccan (Sumber: situs Miesarch).

Hal ini juga dilakukan oleh Utzon, Van Eyck dan Giurgola dalam merancang bangunan gereja. Gereja Katedral Saint Patrick ini juga memiliki kualitas yang serupa dengan bagaimana eksterior dan interior bangunan memberikan suasana dan atmosfir yang berbeda, dan bagaimana cahaya alami memainkan faktor utama untuk memberikan penekanan khusus pada ruang-ruang yang tercipta pada interior bangunannya. Gereja Katedral Saint Patrick mendapatkan cahaya alami yang terkontrol pada bagian atas, sisi bangunan dan pada bagian belakang gereja. Elemen tersebut memberikan kejelasan secara bentuk dan ruang yang tercipta di dalam bangunan, dan pada fasad bangunan sehingga menciptakan kejelasan bentuk terhadap bagian kepala, badan dan kaki bangunan. Pemilihan material yang kontras juga merupakan faktor utama yang memberikan suasana kontras antara interior dan eksterior bangunan. Suasana monokrom dengan penggunaan material kayu, batu alam dan ditambahkan dengan atribut cahaya alami memberikan kelembutan dan ketenangan dalam ruang gereja. Berbeda dengan material eksteriornya yang menggunakan material bertesktur dan bersifat keras.

\section{Program seni}

Salah satu keunggulan dan penting dalam Gereja Katedral Saint Patrick ini adalah kolaborasi antara arsitek utamanya dengan berbagai seniman untuk membentuk dan membantu menciptakan simbol-simbol liturgi yang ada pada Gereja Katolik. Karya-karya seni yang melengkapi Gereja Katedral ini merupakan aspek penting dari bagian konsep desain arsitektur Gereja Katedral Saint Patrick. Romaldo Giurgola (2005) menjelaskan, Pamille Berg mengarahkan program seni tersebut dari awal, berkolaborasi dengan komite penasihat seni yang dibentuk sebagai satu tim desain yang diminta oleh Uskup. Program ini menetapkan seleksi awal dari para seniman, sehingga mereka dapat bekerja dalam beberapa penugasan untuk Gereja Katedral ini selama empat tahun seiring dengan pengerjaan desain bangunan dan konstruksinya. Karya seni yang terdapat dalam proyek Gereja Katedral ini terdiri dari: (1) karya stainless steel dari pengukir Robin Blau (Gambar 11), Anne Ferguson dan Peter Corlett; (2) karya yang terbuat dari kayu oleh desainer Kevin Perkins dan Phillip Cooper; (3) lukisan karya Graham Eadie, dan Rachel Ellis, serta banyak lagi hasil karya seniman-seniman lain yang terlibat. Salah seorang anggota komite penasihat seni, Suster Rosemary Crumlin menyatakan bahwa karya-karya seni pada Gereja Katedral menjadi bagian dari bangunan; memberikan kualitas desain yang mengagumkan dan dapat menyetuh hati manusia tanpa terbelenggu oleh batas waktu. 


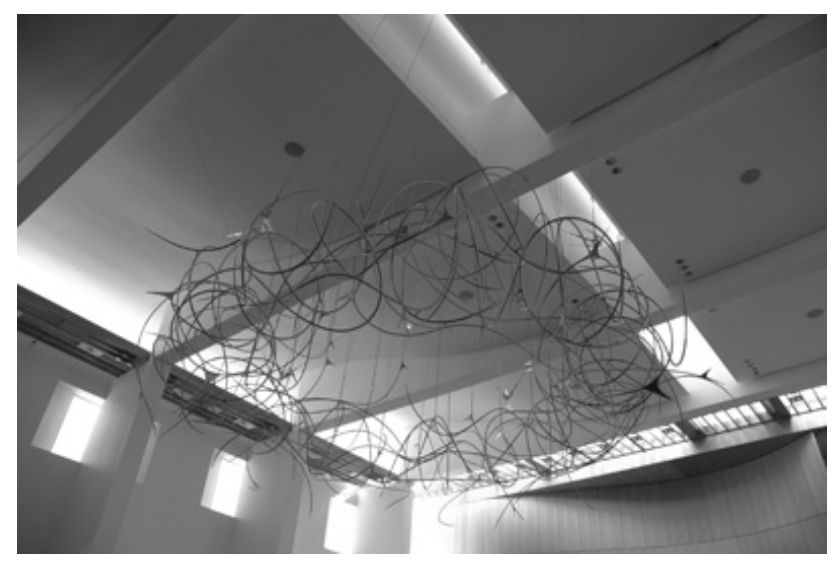

Gambar 11. Karya stainless steel dari pengukir Robin Blau di Gereja Katedral Saint Patrick

(Sumber: Albertus Prawata)

\section{PENUTUP}

Suasana kontras antara elemen lama dan baru (old and new) pada bangunan gereja, didukung oleh perbedaan ruang yang memiliki kualitas vertikal dan horisontal pada skala bangunan lama dan bangunan baru, menekankan ide utama terhadap pentingnya dan sakralnya lokasi Gereja Katedral Saint Patrick. Nilai sejarah dan pentingnya tempat/lokasi gereja ini (sense of place) menjadikannya sebagai elemen dasar dalam arsitektur bangunan Gereja Katedral ini. Komplek Gereja Katedral yang terbentuk dari bangunan-bangunan dan struktur lain yang saling mendukung dan menciptakan ruangruang penghubung memberikan kualitas dan konteks kota pada komplek tersebut. Hal ini juga memberikan suasana yang mengingatkan akan sejarah lokasi tersebut dan juga terhadap kebutuhan dan kegunaan pada saat ini.

Karya seni yang terdapat dalam Gereja Katedral ini memberikan kualitas yang tinggi dan menjadi satu kesatuan dalam desain arsitektur Gereja Katedral Saint Patrick. Karya-karya tersebut juga tidak lupa memberikan kontribusi dalam menekankan pentingnya elemen tempat/ lokasi gereja ini dengan membawa kualitas lama dan baru. Dalam hal ini, para desainer dan juga petinggi yang terlibat dalam pembangunan gereja menunjukan perhatian lebih terhadap simbol-simbol liturgi agama Katolik, yang didesain dan dikerjakan oleh para seniman untuk memberikan sentuhan kontemporer. Keputusan ini merupakan suatu hal yang sangat baik dan menjadi elemen penting dalam Gereja Katedral Saint Patrick, karena dapat memberikan suatu suasana yag segar dan baru, baik dalam konteks bentuk fisik sebuah gereja itu sendiri, ataupun secara spiritual.

Ide-ide dasar desain dengan memberikan suasana kontras baik terhadap ruang, skala, dan penggunaan material ditujukan untuk menekankan memori terdahulu dan memberikan suatu koneksi terhadap masa lalu, yang memperlihatkan pentingya bangunan Gereja Katedral Saint Patrick. Pembangunan Gereja Katedral Saint Patrick yang baru melibatkan berbagai macam seniman untuk membangun sebuah rumah peribadatan, dan menjadikannya sebuah wadah dan tempat yang nyata untuk melakukan dan menjadi penampung semua kegiatan yang ada pada gereja ini, tanpa melupakan nilai sejarah dan nilai-nilai tradisi yang ada merupakan tujuan utama arsiteknya. Elemen-elemen tersebut menjadi prinsip desain utama yang digunakannya dalam merancang Gereja Katedral Saint Patrick. 


\section{DAFTAR PUSTAKA}

Australian Institute of Architects. (2011). St Patrick's Cathedral, Parramatta. Diakses 21 Juli 2011 dari http://www.architecture.com.au/awards_search?option=showaward\&entryno=20042077.

Giurgola, R. (2005). Saint Patrick’s Cathedral, Parramatta, NSW, Australia. UME, 19, 26 - 33.

Giurgola, R. (2006). Luminous Simplicity: The Architecture and Art of Saint's Patrick Cathedral, Parramatta, (1 ${ }^{\text {st }}$ ed.). Victoria, Australia: Macmilan Art Publishing.

Saint Patrick's Cathedral Parish Parramatta. (2011). History. Diakses 20 Juli 2011 dari http://www.stpatscathedral.com.au/index.php/history 